class or sexual minorities), which sets the described community in a sort of a vacuum. The book opens with a short anecdote of the Congress Party's women's group meeting, where a teenage bride has come to make an official complaint about her in-laws who have been abusing her physically and verbally. Although an intervention is promised, her story is nevertheless dismissed by the majority of women present. That seems to be a recurring theme in the book itself - any hint of violent or traumatic experience is removed from the argument and the silences, although signalled, are not taken into an account. Considering that India is a country where violence against women is significant, that seems a big omission, as those silences alone would make the text a valuable source of knowledge on (non-western) mothering practices.

Overall, Domestic Goddesses presents itself as an anthropological text, and stays within its own confines. Making a significant contribution to current anthropological discussions on kinship and marriage systems in developing societies, it is an interesting text for anthropology students, but leaves a feminist scholar hungry for more. Concepts such as attachment, affection and bonding between mother and child and gendered infant development would contribute greatly to its reading. Motherhood for Donner, and maybe rightly so in the anthropological sense, consists of culturally specific practices to nurture and socialize children into full members of a given society. Clearly each of the themes structuring the book has been important in feminist historical thinking, although there are additional areas that are not mentioned. Although the author objects to motherhood being constituted as natural, unproblematic and apolitical, she describes it primarily through nurture, care, food and marriage - the most traditional (and often oppressive) tropes connected to it. Surprisingly, there is little discussion about how the themes of the five chapters were arrived at and which alternatives were considered, nor is there consideration of the very different understandings of those themes in feminist scholarship. The book's title, in that light, is less ironic than it might be desired - the category 'mother' often remains reified and universalized, despite its strong local positioning.

doi: $10.1057 / \mathrm{fr} .2009 .28$

Marta Zarzycka

\title{
queering reproduction: achieving pregnancy in the age of technoscience
}

Laura Mamo, Duke University Press, Durham and London, 2007, 320pp.,

ISBN 978-0-8223-4078-2, £17.99

In November 2008, along with the historic election in the United States of its first black President Barack Obama, Proposition 8 was passed in the state of 
California. This amendment to the California Constitution, which added a clause that marriage could only exist between a man and a woman, served as a reminder that the battles for queer citizenship rights can not be taken for granted. The terms in which the battle over Proposition 8 were fought - terms such as relatedness, citizenship, who counts as a family and how the boundaries between queer and heterosexual families might be regulated - is illuminated in instructive ways by Laura Mamo's riveting ethnographic study of lesbians' use of technoscience in Queering Reproduction. That the setting for her ethnography is the Bay Area of San Francisco, the queer cosmopolitan Mecca of California, adds a theoretical complexity, and a political urgency, to the insights of Mamo's book.

Queering Reproduction is a welcome addition to a growing body of recent scholarship around the complex practices and experiences of queer families and the discourses of relatedness and familiarism that these families are able to use, and are also constrained by. What Mamo's book shares with this emerging scholarship is a willingness to stretch the terms of sexual identity under which these claims are made, and to engage creatively with the intersections of class, race and gender, which, along with sexuality, form the connective tissue through which everyday experiences of queer families are felt and lived. The new generation of queer scholarship around the family seeks to destabilise the homogenous, universal lesbian mother who was celebrated in much gay-liberation literature in the 1970s and 1980s, and to think through the many other axes of difference besides sexuality that inform the options and actions of queer subjects seeking parenthood. Roisin Ryan-Flood's excellent transnational research, Lesbian Motherhood: gender, families and sexual citizenship (2009) explores the ways in which Swedish and Irish lesbians drew on particular cultural discourses around family and gender in order to produce an account of who could be considered a parent in their families; while Yvette Taylor's Lesbian and Gay Parenting: securing social and educational capital (2009) reminds us that queer parents are classed as well as sexual subjects.

In the book, Mamo examines the sociocultural histories of medical reproductive technologies, from the alternative empowerment practice of self-insemination within lesbian-feminist cultures, to the growing provision of assisted reproduction services by commercial organisations and clinics. She explores lesbian accounts of the decision to pursue parenthood, and of the ways in which donor options are evaluated according to not only biological and genetic risks, but also social and legal ones. She traces the trajectory, for some lesbians, towards 'infertility' medicine that is principally designed to remedy heterosexual childlessness. The shifts towards infertility medicine, or 'Fertility, Inc.' as Mamo refers to it, by lesbians is indicative of wider cultural shifts towards biomedicalisation, in which medical services are enlisted not as cure or treatment but as 'life enhancement' and 'fulfillment', in which the purchase of complex and elaborate biotechnologies has taken queer and feminist 
empowerment away from the turkey baster and into the clinic, and in which the gay men who were once significant actors for lesbians seeking parenthood have become increasingly symbolically sidelined. Parenthood, as a means of creating legibility and legitimacy in a heterosexist society, is a process that is not without its costs for queer parents. Mamo refuses to romanticise the lesbian mother, arguing that in many ways the processes through which more and more lesbians are becoming mothers have come to reflect the consumer orientations of a less civically minded and more isolated world.

In her analysis of these shifts towards Fertility Inc. for lesbians, Mamo is at her best. It is testament to her skills as an ethnographer and her subtlety as a writer that she is able to document the complexities with which some women follow the technological scripts given to them through technoscience while others accommodate, resist, ignore and negotiate these scripts. She remains sensitively attuned to the inequalities of access that the extension of technoscience has engendered for queer families, and also to the powerful ideologies that operate and circulate; which she tentatively concludes might be best termed as a shift from compulsory heterosexuality to compulsory motherhood. 'Queering' reproduction reproduction without sex, sex without reproduction - does not solidify the normal; rather, this 'queering' pushes into and pulls away from normativity, recasting the terms of reproduction itself. Mamo's complex and multi-sited ethnography and her beautifully written and incisive analysis of the stories and accounts she finds there, will be of interest to scholars working within the fields of infertility and biomedicalisation, LGBTP lives and politics, to students of ethnography and social science and to health practioners and clinicians working within reproductive medicine and health, as well as to those interested more broadly in thinking about the relationships between technologies, bodies and identities.

doi: $10.1057 / \mathrm{fr} .2009 .36$

Tracey Jensen 